\title{
The Orthodox Teaching on Image and Likeness
}

\section{Dan MIREA*}

Abstract: The Church teaches that man was created by God in a way apart from the other beings. If the other creatures were created by word, man was created through a special intervention of God, both in regard to the body and the soul. Although man is made up of body and soul, he remains united in his psychophysical being. The soul is not confused with the body, and the body is not a separate reality from the soul, because the body has a plasticizing rationality that remains anchored in the spiritual and unitary reality of God's image in man. The human constitution has a dichotomous character, being made up of God from body and soul, but this dichotomy finds its unity in the image of God, which embraces both the soul and the body. Through the image of God in his being, which is the image of the Trinity, man was created for a life of communion, and not for autonomy or bondage to the world.

Keywords: God's image, communion, Trinity, rationality

The man was created in the image of God, showing the special relation between man and god, and also the human kinship with God. The man received through the breath of life not only biological life, but also the spiritual support of the dialogue with God. Therefore, it is the beginning of the dialogue with God. This dialogue is possible because the man is created "in the

* Priest, ,,Sfầntul Stelian Paflagonul”, Mavrodolu - Pediatrics, Pitești, Romania. 
image" of God. The image of God has a community aspect: the man is not a solitary being; he is a being ascending to the likeness to the Trinity God through a continuous dialogue with other people and with God as Trinity person reality. The fundament and the final structure of the man, the divine image in him, show the tension or the aspiration for the communion with God. The primordial state of the man indicates this tension, but, by sinning, we see that this state was not perfect, but in a process of perfection, because it needed time ${ }^{1}$. The fall of the man does not indicate the lack of the divine image in the man, but the lack of the resemblance, because the man had not arrived to that stage. Thus, we may observe that the man's perfection is not connected to the created world as a whole; it is connected in the difference to this world, assimilating him to the Creator. The image of God refers firstly to the spiritual nature of the man, to reason, feelings and will, in their natural inclination to God, while the likeness is the aim of the man in his spiritual development. The likeness to God can be obtained by remaining inside the good, depending, on one hand, on the action of the spiritual and moral powers of the man, and, on the other hand, by the help of the divine grace ${ }^{2}$. The Orthodox theology does not limit the image of God only to a part of the human being, so not only the body participates to the image, but also the soul, due to their intimate and inseparable union in the human being. We can find this idea to Saint Gregory Palamas, who, in a dispute with Varlaam, expressed the importance of the body in the ascetic effort of the man going forward on the road to the likeness to God and showed that the heart is "the store room of our power and the first bodily organ of

${ }^{1}$ StăniloAe, Teologia Dogmatică Ortodoxă, vol. 1..., p. 280.

${ }^{2}$ Nicolae CHIȚESCU, Isidor TODORAN, Ioan PETREUȚă, Teologia dogmatică şi simbolică, vol. 1, Cluj-Napoca, Renaşterea Publishing House, 2004, p. 392. 
the mind". Therefore, "the grace rules over all the thoughts and parts of the body when the grace enters into the heart"3.

The nature and the role of the man of Earth are defined by the expression "image and likeness" (Genesis 1:26-27; 5: 1, 3; 9: 6 ), an expression containing in a brief formula the entire teaching related to the man in the Old Testament ${ }^{4}$. The theme of the "image" remains a defining aspect for the entire eastern theology and, especially, for the anthropology. Discussed in the ancient philosophy and present in the thinking of the Old Testament, this theme gains a new content, with an immediate Christological reference, in the theology of the New Testament, because the man was created "in the image of God"; the man is the image of the Image, an icon of Christ ${ }^{5}$. The two fundamental coordinates of the Christian anthropology are "the image" and "the likeness" of the man in relation with God, underlining the fact that the man is an embodied spiritual being. We meet a first mention referring to the issue of the "image" and "likeness" in the Old Testament, in Genesis, 1:26-276.

${ }^{3}$ Sfântul Grigorie Palama, Tratatul al doilea din triada întâi contra lui Varlaam in Viaţa şi învătăturile Sfântului Grigore Palama, translated by pr. prof. dr. Dumitru Stăniloae, Bucureşti, Scripta Publishing House, 1993, p. 168.

4 IOAN Bude, “Antropologia Vechiului Testament", în Studii Teologice, anul 41 (1989), no. 3, p. 35.

5 Cătălin PĂLIMARU, “Antropologia omiliilor macariene”, în Studii Teologice, year 2 (2006), no. 3, p. 49.

6 We mention that some Protestant theologians often criticize toughly the „theology of the image", affirming that the Biblical Revelation does not refer to the image of God in the man and the problem of the image is a pure philosophical speculation taken from Hellenism when the Old Testament was translated in Greek; it infiltrated in the Christian thinking when the Greek philosophy met the thinking of the Church. They also affirmed that the theology of the image was generated in the same time by the appearance of uncanonical books of the Old Testament, e.g. The Book of Solomon, written in the Greek environment, therefore taking the idea of 
The Hebrew name for "image" is tselem, translated in

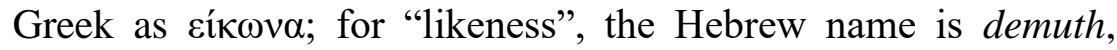
translated in Greek with ó $\mu$ oí $\omega \sigma 1 \zeta$. The root of the Hebrew word tsel, translated as "shadow" or "reflection"; tselem was in the ancient orient the manifestation of an embodiment of something that was represented in this manner. In this context of the term, the man is a reflection of the image of God, an image reflecting God as an Absolute and Personal Reality, to the extent that God can be reflected in His creation ${ }^{7}$. Related to this aspect, the Greek theologian Christos Yannaras affirms that, even if the man is a created existence, he has a personal character, because he is created in the image of the uncreated God, affirmed by the Bible as the Personal and Eternal Life $^{8}$. The core of the personal character of the man is the fact that he was created in the image of God, unlike the other things that were created only by the will of God: "We are not talking anymore of another being form the world; we are speaking of a being distinguished through the will of God from all the others, in order to be the image of God into

image from Platonism (cf. 2, 23). The arguments for these speculation is that, if the image and the likeness would be specific tot eh Biblical Revelation, they should appear more frequent throughout the entire Old Testament, but the Genesis, the Psalms, the Book of Job and the prophets do not mention such thing (Vladimir Lossky, După chipul şi asemănarea lui Dumnezeu, translated by Anca Manolache, Bucureşti, Editura Humanitas, 2006, p. 126-8). Still, the Book of Genesis is accepted by the Protestant theology and this books speaks from the beginning that the man was created ,in the image and likeness of God” (Genesis 1:26-27; 6:3; 9:6), permitting us to affirm that the Protestant critique of the theology of the image is not unsubstantiated.

${ }^{7}$ Ioan BUDE, art. cit., p. 35-6.

${ }^{8}$ Christos Yannaras, Abecedar al credinţei, translated by pr. prof. Constantin Coman, Bucharest, Bizantină, Publishing House, 2007, p. 71. 
the world, an aspect meaning appearance, manifestation, and direct representation of God into the world"9.

The Image contains the reflexive logos (reason) of the Creating Logos, "the will, the freedom, the power or the sovereignty, the purity or the holiness, and the love"10; therefore the man is put in a profound relation with the Son of God, as absolute reason and image of the Father. In this context, the separation of the man from the divine Logos, caused by the sin, meant a separation between image and likeness, in the context in which the man was created in the image of God in order to reach the likeness to $\mathrm{God}^{11}$. This fact can be illustrated in the Biblical Revelation: the man was created in the image of God, as written in Genesis 1:26-27, in order to reach to the likeness with The most High; in the New Testament, Saint Paul scolds the Galatians for their lack of faith, a reason for which Christ was not formed in them (Galatians 4:19). On one hand, we can say that the man must reach the likeness to God, and, on the other hand, that Christ must form in the man, meaning that the likeness to God requires for the image of God in the man to reflect Christ, to be modelled after the image of Christ (Colossians 3:10). This is when the image of God comes to the real meaning, the likeness to God. The likeness to God requires Christ to take the image of the man or, as Saint Justin Popovici observed, requires the Christification of the man as his fulfilment.

The binomial "image-likeness" was the object of complex theological analysis for the Fathers of the Church. Taking into consideration the purpose of the man, the two notions do not overlap, but they complete each other ${ }^{12}$, because the man receives

\footnotetext{
${ }^{9}$ Ibidem, p. 72.

${ }^{10}$ Marin CIULEI, Antropologie patristică , Bucharest, Sirona Publishing House, 1999, p. 108.

${ }^{11}$ Ibidem, p. 109.

${ }^{12}$ Ibidem, p. 48.
} 
the image through creation, as ontological given, and has as purpose to develop the likeness to God. In this situation, Adam, if he would not have fallen, could lead the creation to God, toward its transfiguration. Therefore, we understand that the duty of the man is to extend the borders of Eden to the borders of the Earth, pretending that the entire world is the Paradise ${ }^{13}$. It was necessary for the first man, in a permanent dialogue with God, to ascend together with the entire creation to the maximum pneumatisation, understood not as annulment of the materiality of the human nature and of the cosmos, but as entrance of the divine energy inside them. In general, the theologians agree that "image" should be understood as the human reason and freedom, while "likeness" is achieved by our own effort to become perfect ${ }^{14}$. There is also known the idea according to which the image of God should be understood as reason, feelings and will. Discussing the binomial image-likeness, Origen affirmed that the supreme good is achieving the likeness to God, in all possible ways. The theologian explains the verses from Genesis 1:26-27 by stating that the man receives the image of God through creation as special dignity, while the likeness must be gained by the humans through their activities, by imitating God in good deeds until their death $^{15}$.

This conception is specific to the theologians of Alexandria and Cappadocia. The theologians from Antiochia explained in a different manner the image of God inside the man; their

${ }^{13}$ Justinian CÂRSTOIU, Pietatea şi dreptatea în trăirea omului biblic, in "Studii Teologice", 1999, no. 1-2, p. 109.

${ }^{14}$ Gheorghe CAlciu-Dumitreasa, Crearea lumii, expusă în Hexaemeronul Sfântului Vasile cel Mare, in "Ortodoxia", year 27 (1975), no. 4, p. 640.

${ }^{15}$ Origen, Despre principii, in col. „PSB”, vol. 8, translated and notes by pr. prof. Teodor Bodogae and pr. prof. Constantin Galeriu, Bucharest, Institutului Biblic şi de Misiune al Bisericii Ortodoxe Române Publishing House, 1982, p. 251-2. 
explanation corresponds more to the biblical context from the first chapter of Genesis and refers to the man's dominion on nature, as affirmed Saint John Chrysostom and Teodoret ${ }^{16}$. The first interpretation on the image of God in man became one of the fundamental teachings of the Church. The second interpretation is also justified by the biblical text. The confession of Saint John Chrysostom is reproduced as follows: "The words: 'Let us make mankind in our image, in our likeness' (Genesis 1:26) means nothing else than the fact that the man received dominion over everything on earth" ". He also said: "the words 'in our image' does not mean image by the being, but image by dominion" 18 . Also, in his Homilies on Genesis, Saint John Chrysostom maintains the same direction when interpreting the verse from Genesis 1:26: "after God had said: 'Let us make mankind in our image, in our likeness', He completed the discourse with words showing us the meaning of 'image'. 'They may rule over the fish in the sea and the birds in the sky, over the livestock and all the wild animals, and over all the creatures that move along the ground'. Therefore, the word 'image' must be understood as dominion and nothing else, because God created the man to be lord on everything on earth; nothing on earth is bigger than the man and all is under his dominion" $"$.

${ }^{16}$ Hristu ANDRUTOS, Simbolica, translated by PF Iustin, Bucharest, Anastasia Publishing House, 2003, p. 230.

${ }^{17}$ Sfântul IOAN GURĂ DE AUR, Despre necazuri şi biruirea tristeţii, Bucureşti, Institutului Biblic şi de Misiune al Bisericii Ortodoxe Române Publishing House, 2002, p. 117.

${ }^{18}$ Idem, Nouă cuvântări la Cartea Facerii, translated by pr. prof. Dumitru Fecioru, Bucureşti, Institutului Biblic şi de Misiune al Bisericii Ortodoxe Române Publishing House, 2008, p. 307.

19 Idem, Omilii la Facere, in col. „PSB”, vol. 21, translated by pr. prof. Dumitru Fecioru, Bucureşti, Institutului Biblic şi de Misiune al Bisericii Ortodoxe Române Publishing House, 2003, p. 85. 
Saint Gregory of Nyssa explains concretely the image of God in man. For this Father, the idea of image of God contains all that characterise God, meaning that the man becomes part to the divine good things; God put in the man something oh His kind, thus, the man is naturally kindred to the One contained in the Eucharist. The man was given life, reason, wisdom, and immortality and God put in man's nature the principle of goodness ${ }^{20}$. The man was created after an especially beautiful Model $^{21}$, was offered freedom and the dominion on the world: "the human nature was destined from the beginning to be a queen (...), to have dominion on others, because is like the King of all beings - a living painting presenting as common with his Model the dignity and the name"22. God planted in man "the righteousness, the lack of passions, the happiness, the alienation from all evil and many other similar gifts, showing the likeness of the man with God. These are the flowers growing in the image of God that are used to adorn the human nature!"23 Saint Gregory of Nyssa also said that, similar to the Divine Nature that cannot be understood in its essence by any being, the nature of the soul and the nature of the human mind is not cognoscible to us, proving against a common feature with God and explaining another aspect of the image of God in man: "If one of the features of the divine Being is that it cannot be understood by the human

${ }^{20}$ Sfântul GRIGORIE DE NYSSA, Marele cuvânt catehetic, in col. „PSB”, vol. 30, Scrieri exegetice, dogmatico-polemice şi morale, in col. „PSB”, vol. 30, translated and notes by pr. prof. Teodor Bodogae, Bucureşti, Institutului Biblic şi de Misiune al Bisericii Ortodoxe Române Publishing House, 1998, p. 2945.

${ }^{21}$ Idem, Despre facerea omului, in col. „PSB”, vol. 30..., p. 22.

${ }^{22}$ Ibidem, p. 23.

${ }^{23}$ Ibidem. 
mind, than, in this aspect, too, the image must be similar to the Model"24.

We can observe that, no matter the manner in which they understood the image of God in man, the Holy Fathers confessed unanimously that the image of God in man shows the special dignity of the man in relation with the rest of the creation; this proves that the man was not created to be a slave of the nature or to destroy the nature, but to master it in the name of $\mathrm{God}^{25}$. Thus, the image of God is also a mission. Saint Basil the Great considers that the image is likeness in potency, while the likeness is image in actuality ${ }^{26}$. The image of God in man represents in the same time a gift and a purpose, because the man finds his ontological content in the Archetype. Image and likeness mean that the man tends, in his nature, toward the One that is the Divine Image. God made all these gifts to the man, for the gifts to be inside the man the possibility to become "image of God".

Another important aspect that must be underlined is the fact that the man is "in the image of God" and not "the image of God", which are different things. Saint Paul teaches in many verses of the New Testament that the divine Logos is the "image of God" (2 Corinthians 4:4), "the image of the invisible God" (Colossians 1:15), and "the exact representation of His being" (Hebrews 1:3). Therefore, the Son of God is the Image of God, the Living and eternal Icon of the Father, while the man is created "in the image of God", after the model of the divine Logos - the image of the Image of $\operatorname{God}^{27}$. This is the difference between

\section{${ }^{24}$ Ibidem, p. 34.}

${ }^{25}$ Dumitru PoPescu, Iisus Hristos Pantocrator, Bucureşti, Institutului Biblic şi de Misiune al Bisericii Ortodoxe Române Publishing House, 2005, p. 169.

${ }^{26}$ Ibidem, p. 16.

27 Irineu POPA, „Fiul lui Dumnezeu în deşertarea de Sine şi lucrarea dumnezeirii Sale în îndumnezeirea oamenilor", în Mitropolia Olteniei”, vol. 65 (2013), no. 1-4, p. 10. 
being the Image of God and being "in the image of God". Thus, the Christian anthropology has Christological perspective. Based on this reality, the Son of God made Himself Man, in order to restore the image of God in the man perverted by sin. This is the reason for His incarnation as the second Person in the Holy Trinity, the Son, and not the Father and the Son. The Logos, as Image of God, restores the image of God in the man perverted by sin. The Serbian theologian Justin Popovici wrote: "God-Logos made Himself Man to bring the man back to his Archetype, Who is his Creator, because the man was created, in the beginning, through God-The Logos, with the character of God-Logos, the character of His "logosity" 28. Related to this issue, the Greek theologian Nikos Matsoukas wrote: "The biblical teachings and the theology, in complete agreement with the teachings, attribute the image, as principle, to the Word, to the second Person of the Holy Trinity. Therefore, Christ is called the image (icon) of God as creator principle and has naturally an existential and direct connection with the Person of God the Father as 'radiance' of

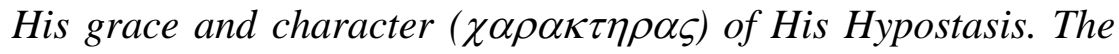
Logos or the incarnated Christ (as Logos) is considered the natural image of the Father in the vision of the later development of the Orthodox theology. Therefore, Christ is worshiped in the divine order. This image, traditionally, is considered to belcalled natural, in opposition to the built images (icons)" 29 .

The likeness of the man to God involves the free and conscious participation of the man to this work, as a co-operation between man and the saving divine grace, because "the likeness is not imposed to the human nature. It is a virtuality indestructibly

${ }^{28}$ Sfântul IUSTIN POPOVICI, „Biserica - Tradiţia divino-umană”, translation by Branislav Stancovic, în Ortodoxia, anul XXXIV, no. 4, octomber december 1982, Bucureşti, p. 57.

${ }^{29}$ Nikos A. MATSOUKAS, Teologia Dogmatică şi Simbolică. vol. 2, translation by Nicuşor Deciu, Bucureşti, Bizantină Publishing House, 2006, p. 145-6. 
connected to freedom, soliciting the initiative and the work of the man. He can be more or less in the state of likeness to God, but he cannot be more or less in the image of God (...). The image is the reflection of the divinity in us and the likeness to our deification. Our image shows us the 'how' of the universe and the likeness of 'why", 30 , because "the actualisation of the iconic capacity, of image of the Son, toward the union with God in Trinity, involves an aware and free participation of the man to the sacrament of his own image" 31 . The achievement of the likeness of the man to God also has a gnoseological perspective because "the meaning and the fulfilment of the man reside in the participation to the image of the Father, Who is the Son, where the man receives the knowledge of God and the renewal of the Holy Spirit" 32 .

The fact that the man was created in the image of God involves a special dignity of the man in relation with the rest of the creation. Saint Gregory Palamas observes another profound aspect of the image of God in man: "the fact that we know that we are 'in the image' of our Creator does not allow us to worship the sensitive world nor the intelligible world"33. Saint Gregory Palamas teaches that all the rational natures (humans and angels) were created in the image of God, but the man is more in the image of God than the angels, because the man is not only spirit, he also has a body, and, especially because God made Him Man and came in maximum proximity to the people. Related to

30 Jean Kovalevski, Taina originilor, translation by D. Mezdra, Bucureşti, Anastasia Publishing House, 1996, p. 74-75.

31 Florin CARAgIU, Antropologia iconică reflectată în opera Părintelui Dumitru Stăniloae, Bucureşti, Sofia Publishing House, 2007, p. 71.

${ }^{32}$ Ibidem, p. 62.

${ }^{33}$ Sfântul GRIGORIE PALAMA, op. cit., p. 254. 
likeness, the angels are more in His likeness than the humans, when we are referring to the good angels ${ }^{34}$.

After the fall of Adam, the image of God in man did not disappear, it was only altered and the man did not go forth on the path of likeness. By sinning, the image of God in man was altered but not destroyed or abolished. None of the spiritual powers, where the image was impregnated, was destroyed. The human spiritual constitution was altered, but not ruined. The capacity of knowledge and the desire for goodness remained inside the man, but in a weaker form, because, after the fall, Adam and Eve heard and knew the voice of God and felt guilty and ashamed. The capacity to know the religious and moral truth and the capacity to fulfil the moral norm are not lacking in the fallen man. They are proved by the revelations and the commandments brought to the man after the fall, highlighting the consequences of respecting or violating them, through the knowledge capacity and the freedom of the will. The temptation to sin can be mastered by the fallen man (cf. Genesis 4, 7), who has the power to avoid the evil and the death, choosing life (cf. Deuteronomy 30: 14; 15:19). Christ will bring back what Adam lost. Moreover, in Christ, the man is in a superior state to the state in which Adam was before his fall. The man can achieve the likeness to God through the divine help and the practice of the virtues. "The road from image to likeness is determined by practicing the virtues, but also by the presence of the divine grace, from which the image cannot be separated. The grace shapes the man in the image of the Saviour. The life in Christ is a journey from 'in the image' to the Image. Therefore, the humanity has its beginning and its end in Christ, Who

${ }^{34}$ Ibidem, p. 285. 
restored the image and also found the lost image in order to recreate it" 35 .

Due to the fact that he was created in the image of God, the man is a person, as God is a Personal Reality. Thus, the man is not blind nature. The man is not the one fulfilling his meaning through the cosmos; instead the cosmos must be personalised, fulfilling its meaning and being saved through the man, because "the man is the hypostasis of the entire cosmos participating to his nature, while the earth discovers its personal, hypostatic meaning in the man" 36 . The man represents for the universe the hope for receiving the grace and being united with God, not in a Pantheist manner (cf. Romans 8:19-22). In the same time, the man represents for the universe the danger of failure and fall, because the man is a free being. The freedom of the man is a feature of the image of God in the man. The mission of the man in the universe cannot be fulfilled unless the connection of the human image with God, his Prototype, is re-established ${ }^{37}$.

Related to the journey of the man from image to likeness, father Dumitru Stăniloae wrote: "This maximum union with God, the impregnation of the man by the wholeness of God, is the deification of the man. The image of God in man is given for this purpose, as an aspiration to His absolute model. The fulfilment of the image resides also in the maximum likeness to God. The image includes, as divine commandment, the strong inclination of the man toward his deification" 38 . In the same time, as father

35 Vasile SORESCU, Cunoaşterea lui Dumnezeu la Sfântul Ioan Gură de Aur, Piteşti, Paralela 45 Publishing House, 2008 p. 103.

${ }^{36}$ Vladimir LOSSKY, Introducere in teologia ortodoxă, translated by Lidia şi Remus Rus, Sophia Publishing House, Bucureşti, 2006, p. 90.

${ }^{37}$ Ibidem.

38 Dumitru Stănilone, Teologia Dogmatică Ortodoxă, vol. 1, $2^{\text {nd }}$ edition, Bucureşti, Institutului Biblic şi de Misiune al Bisericii Ortodoxe Române Publishing House, 1996, p. 414. 
Dumitru Stăniloae said, the likeness does not mean only a finality understood as deification, but also the entire journey of the image in its development ${ }^{39}$ as likeness or deification. The man would not be a man without the image of God, because this is a defining feature, lifting the man above the rest of the creation and separating him from $\mathrm{it}^{40}$. The separation should not be understood as a total and brutal rupture of the man from the creation; the separation means that the man cannot and must not be confounded with the creation or the universe. Without the image of God, the man would not be man; he is achieved only when achieving the likeness to God.

Ecclesiological, the relation between image and likeness is placed in the light by the Sacrament of the Baptism. Through Baptism, the human nature is ontologically grafted in Christ, so the devil cannot kidnap it through sin and death. The healing is centred on the kinship with Christ and on the salvation from the fear of death. "The strongest power of the devil is the death, which is destroyed only in the body of Christ, where the believers are engaged in a continuous fight against Satan, through the endeavour of a selfless love. This fight against the devil and the endeavour for the selfless love are centred on the Eucharistic and corporal life of the local community" 41 . The Baptism rebuilds the man as Paschal being and hypostasis in a living relation with the entire creation ${ }^{42}$. Not only grace is achieved in this mysterion; the

${ }^{39}$ Ibidem, p. 415.

${ }^{40}$ Doru Costache şi Adrian CAZACU, „Experienţa paradisiacă a omului în viziunea creştinismului occidental. Aspecte antropologice", in Ortodoxia, vol. 56 (2005), no.1-2, p.109.

${ }^{41}$ Ioannis ROMANIDES, „Original Sin According to St Paul”, in St Vladimir's Theological Quarterly, vol. 4 (1955), n0. 1, p. 24.

${ }^{42} C f$. pr. prof. Boris BoBRINSKOY, Impărtăşirea Sfântului Duh, translated by Măriuca and Adrian Alexandrescu, Bucureşti, Institutului Biblic şi de Misiune al Bisericii Ortodoxe Române Publishing House, 1999, p. 130-54. 
entire movement of the spiritual life is fundamentally initiated. This rebuilding of the created being was highlighted in the ancient times by the conduct of the Sacrament to the celebration of the Resurrection, Christmas and Epiphany, events expressing the life communion with God under the form of a journey to a happy existence. The Baptism in the community, determining the entire liturgical expression of the Church, made undeniable the deep connection between the individual life and the life in the community. The Paschal meaning of the ecclesial community was reflected in the Paschal dimension of the hypostatic existence. Thus, every believer lived in his own life the journey of the entire Church. The Baptism opens the life involving the free service of each soul in accordance with the journey of the parochial community. Therefore, the Sacrament cannot be placed in the past of one's own existence, because it would be damaged the essence of the communion in which the man is becoming part through the Baptism.

The kinship of the man with God-man reveals the vocation of the real service. The union with Christ shows what it means to live according to the divine reasons. Simply expressed, "through Baptism, each Christian receives the form of Christ", becoming a king, a prophet and a priest ${ }^{43}$. The three types of service are oriented toward the others and toward the creation; they bring into actuality a journey not moving toward goodness. The priesthood, the prophecy and the dominion have coherence inside a community. The prophets of the Old Testament, e.g., were called to become bearers of a divine message beyond the individual life. The Baptism put the man in the condition of being characterised by the community service and involves a work for

${ }^{43}$ Pr. prof. Ilie Moldovan, „Botezul ca chemare la asemănarea cu Hristos. Consecinţele Botezului asupra vieţii ecleziale şi morale (implicaţii catehetice şi misionare)", in: Revista Teologică, vol. 2 (1992), no. 3, p. 6-7. 
the affirmation of the Trinitarian vocation. This affirmation of the vocation highlights the relationship between hypostasis and parish.

The prophetic service of the believers is brought into actuality through the confession of faith. The confession of faith represents the convergence of the human world toward the happy existence of the angel cohorts. It put to good work the gift of knowing the Truth and expresses the perfect Revelation of God in the life of each believer. The faith of the Church is not a statement - meaning a system built through individual rational efforts, although it frames the human existence and includes the hypostatic enunciation. The faith of the Church is not claimed from the personal evaluation, because it is not individualised and enriched essentially by the human person attempting to assume the Truth. The man can show the truth of the faith, participate to the gift of the Revelation of God and, based on this participation, to manifest hypostatically the faith of the Church. Still, the man cannot master the truth. It is very suggestive the fact that the Dogmatic systemises the teachings of faith in an argumenta presentation along the Revelation of God and of His creating, saving and sanctifying action. This gesture shows that the work of God itself is the content of the faith; the impression that this "content" could be impersonal and abstract or mastered by any human being is refused. The prayer before reading the Gospel explicitly expresses the state of participation and communion: "Illumine our hearts, O Master Who lovest mankind, with the pure light of Thy divine knowledge. Open the eyes of our mind to the understanding of Thy gospel teachings. Implant also in us the fear of Thy blessed commandments, that trampling down all carnal desires, we may enter upon a spiritual manner of living, both thinking and doing such things as are well-pleasing unto Thee. For Thou art the illumination of our souls and bodies, $O$ Christ our God, and unto Thee we ascribe glory, together with 
Thy Father, Who is from everlasting, and Thine all-holy, good, and life-creating Spirit, now and ever and unto ages of ages" 44 . The Christian who does not preach the Truth, accommodating his life to the rhythm of the Church, loses the prophetic vocation and the doxological calling. He remains outside the parish community. In the same time, the parish community that is not anchored in the believers' daily experience remains a prisoner of confessional formulas, which are not existentially assumed; this church is placed against an authentic prophetic service.

The sacerdotal work of the baptised person requires a continuous sacrifice. All people of God must participate to the sacrifice and the mediation of the Church, which are manifested in the Eucharist Sinaxis. Anyone remaining away from Eucharist is placed outside the sacerdotal vocation. The ascetic effort and the healing are directed to the moment of the union with the Body and the Blood of the Saviour. The sacerdotal service of the people depends on the Eucharist communion, where all that is wasted becomes gathered, the prophecies are fulfilled and all those hidden to the genesis are revealed. Away from Eucharist, the man is also separated from the priesthood established through Baptism. The canons are very explicit on this matter. The Apostolic Canon 9, i.e., states the curse of those entering the Church without staying for prayer and Eucharist ${ }^{45}$.

This is a manner for underlining the necessity of the continuous answer to the saving call of the Incarnated Son. Without the Eucharist, one is kidnapped by the "understanding wolf" and lives apart from the Church. Willing to reclaim the canonical exigence of the Orthodoxy, many clergymen drew the

44 Liturghier (2012), Bucureşti, Institutului Biblic şi de Misiune Ortodoxă Publishing House, p. 147-8.

45 Ioan N. FlocA, Canoanele Bisericii Ortodoxe. Note şi comentarii, $3^{\text {rd }}$ edition, Sibiu, Arhiepiscopiei, Publishing House, 2005, p. 13. 
attention on the various "forms of communion": by hearing, by seeing, by prayer and by Eucharist. These types of approach must be taken into consideration in a prudent manner. In the Tradition of the Fathers, these "forms of participation" have an ascetic character, preliminary to the Eucharist union with Christ. The ascetic work is an affirmation of the sacerdotal service, without representing a perfect achievement of the sacerdotal service. The believers advance toward their union with Christ by hearing, seeing and praying ${ }^{46}$, but the union is fulfilled only through Eucharist. Saint John Chrysostom shows in the Third Homily on Ephesians, referring to the necessity of the Eucharist: "When the body partakes not of this natural food, when the pores are stopped up, then it mortifies; when the ducts are closed, then it is palsied. So is it with us also, when we stop our ears, our soul becomes palsied [...] I observe many partaking of Christ's Body lightly and just as it happens, and rather from custom and form, than consideration and understanding. When, saith a man, the holy season of Lent sets in, whatever a man may be, he partakes of the mysteries, or, when the day of the Lord's Epiphany comes. And yet it is not the Epiphany, nor is it Lent, that makes a fit time for approaching, but it is sincerity and purity of soul. With this, approach at all times; without it, never. [...] Art thou not worthy of the Sacrifice, nor of the participation? If so, then neither art thou of the prayer" 47 .

The relation between hypostasis and community is shaped by the service to which the man is lifted through Baptism. The divine vocation of the neophyte "is the expression of the man as master of a new world" and "his engagement in a work made by

${ }^{46} C f$. pr. prof. Dumitru STĂNILOAE, „Teologia Euharistiei”, in Ortodoxia, year 1969, no. 3, p. 349-50.

${ }^{47}$ Sfântul IOAN GURĂ DE AUR, Omilii la Epistola către Efeseni, translated by arhim. Theodosie Athanasiu, Iaşi, Daica Publishing House, 1902, p. 30-1. 
Christ Himself" ${ }^{48}$. The responsibility for the creation and for the history receives eschatological proportions through the service, meaning that the man is called to show on earth the heavenly communion. The ideal of the Christian is not to remain in the history, but to make the history eternal. After the Baptism, the man lives sacramentally the Kingdom of Heaven, being "fellow citizens with God's people and also members of his household" (Ephesians 2:19). The eschatological experience of the neophyte discovers the beauty of a creation in a hypostatic manner and is in accordance with the continuous experience in the liturgical community. The coordinates of this experience are determined for the Church and also for the believer. They impose to the man a certain estrangement from the worldly thoughts - "I am not praying for the world" (John 17:9) ${ }^{49}$. To a parochial level, the estrangement from the worldly thoughts is manifested in the organisation of the social reality around the evangelical and liturgical exigencies. The philanthropic actions are secondary in

${ }^{48}$ Pr. prof. Ilie Moldovan, Botezul ca chemare la asemănarea cu Hristos. Consecinţele Botezului asupra vieţii ecleziale şi morale (implicaţii catehetice şi misionare), in "Revista Teologică", vol. 2 (1992), no. 3, p. 8.

${ }^{49}$ The words of a monk are enlightening: "When I was young, I used to have a spiritual Father who loved to go in the farthest desert and live there in Hesychasm. One day, I said to him: 'Why are you always going in the desert, Avva? To me, it seems that the one staying close to the world, seeing the cause of the temptation and, in the same time, refusing them for the love of God, is more welcomed than the one that does not see the temptations and their causes.' The Elder answered: 'Believe me, son, that a man cannot use the world until he reaches the state of Moses, almost becoming a son of God. I am a son of Adam, as my father was, too. If I see the fruit of the sin, I desire it, I take it, I eat it and then I die. This is why our Fathers used to go in the desert." - Everghetinos. Adunare a cuvintelor şi învățăturilor celor de Dumnezeu grăite, ale purtătorilor de Dumnezeu Părinţi, culeasă din toată scriptura cea de Dumnezeu insuflată, vol. 1, Book I (themes 1-25), Mount Athos, Vatoped Monastery, 2011, p. 218-9. 
this ensemble ${ }^{50}$, because the mission of the Church is not to ensure a comfort and welfare according to the human values, but to lift the world to the gift of the Holy Spirit.

The Baptism offers the premise and the condition of the ecclesial achievement. The Trinity vocation of the service, specific to the hypostatic living, is also building the community life. Based on the prophetical service brought through Baptism, no believer can be indifferent to the confession of ekklesia. Participating to the confession implies cohesion with the exigencies and the necessities of the community. There are various ways to confess the truth and various forms for participating to the teachings of the Church. One can confess by listening, other can work according to the Truth, while another can transform his entire life in a confession of God's presence into the world. No matter the amplitude of the confession and knowledge, it only is useful when useful to the fellow people. Therefore, the community needs commitment. A layman passing from a parish to another, leaving his spiritual fathers in order to achieve his own desires is far from a prophetic service. Assuming the community and listening to the fathers are necessary aspects in every prophetic service. The path of the Christian man is vertically oriented to meeting God.

A second observation refers to the service for each believer. To be a part of the Body requires participating to the sanctifying acts of the Church. The Eucharist and the grace are not optional, but an implicit reality of the Christian life. The canons are

50 Ionel UngureANU (Personalizarea socialului. Inţelesuri teologice ale realităţii sociale, Iaşi, Doxologia Publishing House, 2011, p. 131-2) shows the difficulty of maintaining this horizon: "Obviously, it is not easy to reach and maintain this direction to the eschaton of life, especially socially. A conflict is born, inevitably in a certain stage of the Christian life, between the desire for eternal life and the tendence, sometimes ethical, as Yannaras calls it, to the solicitations of the society". 
extremely explicit on this issue, but, unfortunately, due to the legalist spirit rooting in the eastern thinking, the canonical expressions were separated from the dogmatic teaching and the liturgical realism of the Church was neglected. The vocation of priest of each layperson is manifested during the continuous participation to the Eucharist sacrifice and to the sacred acts. The situation when some priests are reluctant to the believers who desire to receive the Eucharist on each Liturgy is unusual. This reluctance replaced the corporal and community existence with a magic and individualist existence.

A last observation is related to serving God through the Sacrament of Baptism and all the other Holy Sacraments. Various social methods and models were adopted by the pastoral theology and applied in the parochial context. E.g., there were created missionary centres in order to present the message of the Gospel in a language appropriate for young people. The approach based on age and the desire to use the scientific results of psychology, anthropology and sciences are beneficial. It is impossible to create sensitivity in community when classifying people socially. Organising the community on age groups means to cultivate cohesions for each generation. The work of the Church should be based on what is given to each member - the eschatological experience of the baptised person in history. The pressure of the eternity leaves its print on the entire mission and preaching. In the same time, it is an insurer of the real unity of the parochial community. If a believer experiences the eternal life during liturgy in Church and in the daily life of the Church, that believer also experiences the life of the community.

\section{Bibliography}

1. Biblia sau Sfânta Scriptură, Tipărită sub îndrumarea şi cu purtarea de grijă a Prea Fericitului Părinte Teoctist, Patriarhul Bisericii Ortodoxe Române, cu aprobarea Sfântului Sinod, 
Institutului Biblic şi de Misiune al Bisericii Ortodoxe Române Publishing House, Bucureşti, 1990.

2. ANDRUTOS, Hristu, Simbolica, traducere de PF Iustin, Bucureşti, Anastasia, 2003.

3. BobrinsKoY, Boris, Impărtăşirea Sfântului Duh, traducere de Măriuca şi Adrian Alexandrescu, Bucureşti, Editura Institutului Biblic şi de Misiune al Bisericii Ortodoxe Române, 1999.

4. BudE, Ioan, „Antropologia Vechiului Testament”, în Studii Teologice, anul 41 (1989), nr. 3.

5. CAlciU-DumitreasA, Gheorghe, „Crearea lumii, expusă în Hexaemeronul Sfântului Vasile cel Mare", în Ortodoxia, anul 27 (1975), nr. 4.

6. CARAGIU, Florin, Antropologia iconică reflectată în opera Părintelui Dumitru Stăniloae, Bucureşti, Editura Sofia, 2007.

7. CARstoiU, Justinian, „Pietatea şi dreptatea în trăirea omului biblic", în Studii Teologice, an 1999, nr. 1-2.

8. Chitescu, Nicolae, TodorAn, Isidor, PetreutA, Ioan, Teologia dogmatică şi simbolică, vol. 1, ediţia a II-a, Cluj-Napoca, Editura Renaşterea, 2004.

9. CIULEI, Marin, Antropologie patristică , Bucureşti, Editura Sirona, 1999.

10. Costache, Doru, CAZACU, Adrian, „Experienţa paradisiacă a omului în viziunea creştinismului occidental. Aspecte antropologice", în Ortodoxia, vol. 56 (2005), nr. 1-2.

11. Everghetinos. Adunare a cuvintelor şi învăţăturilor celor de Dumnezeu grăite, ale purtătorilor de Dumnezeu Părinţi, culeasă din toată scriptura cea de Dumnezeu insuflată, vol. 1, cartea I (temele 1-25), ediţie bilingvă cu un text stabilit pe baza tradiţiei manuscrise, Muntele Athos, Sfânta Mare Mănăstire Vatoped, 2011.

12. FloCA, Ioan N., Canoanele Bisericii Ortodoxe. Note şi comentarii, ediţia a III-a îmbunătăţită, îngrijită de Sorin Joantă, Sibiu, Editura Arhiepiscopiei, 2005.

13. Kovalevski, Jean, Taina originilor, traducere D. Mezdra, Bucureşti, Editura Anastasia, 1996. 
14. Liturghier (2012), Bucureşti, Editura Institutului Biblic şi de Misiune Ortodoxă.

15. LOSSKY, Vladimir, După chipul şi asemănarea lui Dumnezeu, traducere de Anca Manolache, Bucureşti, Editura Humanitas, 2006.

16. IDEM, Introducere în teologia ortodoxă, traducere de Lidia şi Remus Rus, Editura Sophia, Bucureşti, 2006.

17. MatsoukAs, Nikos A., Teologia Dogmatică şi Simbolică. vol. 2, traducere de Nicuşor Deciu, Bucureşti, Editura Bizantină, 2006.

18. Moldovan, Ilie, „Botezul ca chemare la asemănarea cu Hristos. Consecinţele Botezului asupra vieţii ecleziale şi morale (implicaţii catehetice şi misionare)", în: Revista Teologică, seria nouă, vol. 2 (1992), nr. 3.

19. Origen, Despre principii, în col. „PSB”, vol. 8, traducere, note de pr. prof. Teodor Bodogae şi pr. prof. Constantin Galeriu, Bucureşti, Editura Institutului Biblic şi de Misiune al Bisericii Ortodoxe Române, 1982.

20. PALIMARU, Cătălin, „Antropologia omiliilor macariene”, în Studii Teologice, anul 2 (2006), nr. 3.

21. PopA, Irineu, „Fiul lui Dumnezeu în deşertarea de Sine şi lucrarea dumnezeirii Sale în îndumnezeirea oamenilor", în Mitropolia Olteniei, vol. 65 (2013), nr. 1-4.

22. POPESCU, Dumitru, Iisus Hristos Pantocrator, Bucureşti, Editura Institutului Biblic şi de Misiune al Bisericii Ortodoxe Române, 2005.

23. RoMANIDES, Ioannis, „Original Sin According to St Paul”, în: St Vladimir's Theological Quarterly, vol. 4 (1955), nr. 1.

24. Sfântul GRIGORIE DE NYSSA, Marele cuvânt catehetic, în col. „PSB”, vol. 30, Scrieri exegetice, dogmatico-polemice şi morale, în col. „PSB”, vol. 30, traducere şi note de pr. prof. Teodor Bodogae, Bucureşti, Editura Institutului Biblic şi de Misiune al Bisericii Ortodoxe Române, 1998.

25. Sfântul IOAN GURA DE AUR, Despre necazuri şi biruirea tristeţii, Bucureşti, Editura Institutului Biblic şi de Misiune al Bisericii Ortodoxe Române, 2002. 
26. Sfântul IOAN GURA DE AUR, Nouă cuvântări la Cartea Facerii, traducere de pr. prof. Dumitru Fecioru, Bucureşti, Editura Institutului Biblic şi de Misiune al Bisericii Ortodoxe Române, 2008.

27. Sfântul IOAN GuRA DE AUR, Omilii la Facere, în col. „PSB”, vol. 21, traducere de pr. prof. Dumitru Fecioru, Bucureşti, Editura Institutului Biblic şi de Misiune al Bisericii Ortodoxe Române, 2003.

28. Sfântul IUSTIN POPOVICI, „Biserica - Tradiţia divino-umană”, trad. Branislav Stancovic în Ortodoxia, anul XXXIV, nr. 4, octombrie - decembrie 1982, Bucureşti.

29. Sorescu, Vasile, Cunoaşterea lui Dumnezeu la Sfântul Ioan Gură de Aur, Piteşti, Editura Paralela 45, 2008.

30. StaniloAe, Dumitru, Teologia Dogmatică Ortodoxă, vol. 1, ediţia a doua, Bucureşti, Editura Institutului Biblic şi de Misiune al Bisericii Ortodoxe Române, 1996.

31. StAnILOAE, Dumitru, „Teologia Euharistiei”, în Ortodoxia, anul 1969, nr. 3.

32. UNGUREANU, Ionel (Personalizarea socialului. Înţelesuri teologice ale realităţii sociale, Iaşi, Editura Doxologia, 2011.

33. Viaţa şi învăţăturile Sfântului Grigore Palama, traducere de pr. prof. dr. Dumitru Stăniloae, Bucureşti, Editura Scripta, 1993.

34. YANNARAS, Christos, Abecedar al credinţei, traducere de pr. prof. Constantin Coman, Bucureşti, Editura Bizantină, 2007. 